\title{
URGENSI LITERASI DIGITAL BAGI SANTRI MILENIAL DI PONDOK PESANTREN RAHMATUTTHOYIBAH AL IFLAHAH GUNUNG KALER TANGERANG
}

\author{
Mukhlisin' $^{1)}$, Fil Isnaeni2), Nurjaya ${ }^{3)}$, Mukhoyyaroh $^{4)}$, A. Ari Masyhuri ${ }^{\text {5) }}$ \\ ${ }^{1}$ Program Studi Manajemen S1, Fakultas Ekonomi, Universitas Pamulang \\ 2,3 Program Studi Akuntansi S1, Fakultas Ekonomi, Universitas Pamulang \\ ${ }^{4}$ Program Studi Sastra Inggris, Fakultas Sastra, Universitas Pamulang \\ ${ }^{5}$ Program Studi Teknik Informatika, Fakultas Teknik, Universitas Pamulang
}

\begin{abstract}
Abstrak
Hadirnya teknologi digital membawa dampak pada pola pendidikan pesantren dan pola relasi antara pesantren dan masyarakat. Selain alasan efisiensi dalam belajar, akses informasi yang lebih luas, dunia digital memang menjadi sarana baru dalam memperoleh dan menyampaikan ide gagasan dan pendapat keagamaan. Akan tetapi banyak yang mengantisipasi hadirnya media di pesantren karena media digital juga memiliki dampak negatif. Di antaranya adalah mempengaruhi pola interaksi dan belajar para santri di mana tradisi muwajjahah (face to face/tatap muka) dalam belajar, tradisi istimbat (mencari referensi) lewat kitab-kitab turast akan digantikan dengan tradisi googling dan face to screen atau tradisi tatap layar. Dampak negatif ini bisa diminimalisir dengan adanya kemampuan literasi digital. Atas dasar itulah, maka dosen agama Universitas Pamulang melakukan bekerjasama dengan Ponpes Rahmatutthoyibah Al Iflahah jln Ki Cakung desa Kandawati kecamatan gunung Kaler kab Tangerang pada pengabdian kepada masyarakat (PKM) untuk memberikan penyuluhan pada santri dan dewan guru (ustadz) di lingkungan pesantren. Pelaksanaan PKM mewujudkan peran aktif dari kiprah perguruan tinggi langsung kepada masyarakat berkaitan dengan literasi digital pesantren. Metode pelaksanaan kegiatan Pengabdian kepada masyarakat bersifat pelatihan dan penyuluhan dengan integreting visual thinking method. Metode yang mengintegrasikan beberapa metode visual, ceramah, diskusi, berpikir, dan menemukan solusi yang dihadapi santri dalam proses belajar di pesantren.
\end{abstract}

Kata Kunci: Literasi Digital, Santri

\begin{abstract}
The presence of digital technology has an impact on the pattern of pesantren education and the patterns of relationships between pesantren and society. Apart from reasons of efficiency in learning, wider access to information, the digital world has indeed become a new means of obtaining and conveying religious ideas and opinions. However, many anticipate the presence of media in pesantren because digital media also has a negative impact. Among them are influencing the interaction and learning patterns of the students where the muwajjahah tradition (face to face) in learning, the istimbat tradition (looking for references) through turast books will be replaced with the googling and face to screen traditions or the tradition of seeing screens. This negative impact can be minimized with digital literacy skills. On this basis, religious lecturers at Pamulang University collaborated with Ponpes Rahmatutthoyibah Al Iflahah jln Ki Cakung, Kandawati village, Gunung Kaler sub-district, Tangerang district in community service (PKM) to provide counseling to students and teacher councils (ustadz) in the
\end{abstract}




\begin{abstract}
pesantren environment. The implementation of PKM embodies the active role of higher education directly to the community related to the digital literacy of Islamic boarding schools. The method of implementing community service activities is in the form of training and outreach with an integrating visual thinking method. A method that integrates several visual methods, lectures, discussions, thinking, and finding solutions faced by students in the learning process at the pesantren.
\end{abstract}

Keywords: Digital Literacy, Santri

Correspondence author: Mukhlisin, dosen01226@unpam.ac.id, Tangerang, Indonesia

\title{
PENDAHULUAN
}

Hadirnya lompatan teknologi digital telah membawa perubahan yang signifikan pada kehidupan perpolitikan, pendidikan hingga sosial keagamaan di Indonesia. Pada masyarakat religious, teknologi digital memberikan berbagai macam informasi keagamaan yang bisa dengan leluasa diakses oleh masyarakat umum. Sebuah studi yang dikembangkan oleh Nadirsyah Hosen misalnya, dia menyebutkan bahwa kebutuhan akan petunjuk-petunjuk keagamaan (fatwa) di tengah masyarakat modern banyak dilakukan secara virtual dimana interaksi ini mereduksi relasi interpersonal keagamaan. Pada wilayah pendidikan, perkembangan teknologi yang semakin pesat turut pula merubah pola dan model pendidikan dimana pengetahuan dan informasi selain ditransmisiskan secara konvensional, juga melalui transmisi digital seperti email, blog, word press, video tutorial dan lain sebagainya.

Secara spesifik, literasi digital sebagai bagian dari transformasi pesantren adalah terma baru yang mucul setelah kehadiran internet, akan tetapi penyelidikan cikal bakal dari tranformasi literasi ini telah banyak dikembangkan oleh para ahli. Karel Steenbrik misalnya yang meneliti pesantren lebih dari tiga dekade yang lalu, dimana literasi digital belum popular, dia berpendapat bahwa transformasi pesantren pada akhir abad 20 sangat signifikan, hal ini ditenggarai dengan pola pendidikan yang awalnya adalah sorogan dan bandongan kemudian mengadopsi sistem kelas dan madrasah, transformasi ini dilakukan terus menerus sebagai proses adaptasi pesantren terhadap perkembangan pendidikan. Selain system kelas, pesantren juga mengalami perubahan yang signifikan pada kurikulum. Perkembangan pesantren yang lebih progresif ini digambarkan oleh Zamakhsyari Dhofier dimana dia berpendapat bahwa pesantren mengalami transformasi yang massif puncaknya pada masa pascareformasi dimana banyak sekali pesantren salaf yang mencangkokkan keilmuan pesantren berbasis kitab salaf dengan kurikulum nasional berbasis pengetahuan modern (Zamakhsyari Dhofier,2011). Sebagai imbasnya adalah adanya diversifikasi literasi dimana pesantren tidak hanya terfokus mempelajari al-kutub al-sofro 'kitab kuning' sebagai kitab induk pesantren (turast), tetapi juga alkutub al-baidho' 'buku putih', majalah, dan koran. Hal ini menunjukan adanya keterbukaan pesantren terhadap keilmuan kontemporer yang progresif dan perangkat pembelajarannya yang modern (Abu Yazid, 2018).

Literasi digital sebagai perubahan dan transformasi pada model pendidikan pesantren membawa arah baru literasi di mana para santri bisa secara bebas mengakses informasi, baik berupa berita, ebook, jurnal ataupun video tutorial yang beredar luas di luar dinding pesantren. Perlu dijelaskan bahwa hadirnya literasi digital di pesantren 
masih menjadi hal yang baru dimana tidak semua pesantren memiliki kebijakan yang sama. Beberapa pesantren salaf yang masih bertumpu pada tradisi klasik kepesantren masih membatasi akses informasi umum secara bebas. Pelarangan ini dengan cara tidak memperbolehkan santri membawa alat komunikasi portable (baik handphone ataupun laptop) sebagai piranti utama dalam literasi digital. Akan tetapi di beberapa pesantren modern, alat komunikasi portable diperbolehkan untuk mengakses informasi secara lebih luas. Perubahan kebijakan ini menjadi tonggak penting dalam kajian kepesantrenan (pesantren studies) yang oleh Yazid disebutkan bahwa pesatren berusaha membuka diri kearah yang lebih tranformatif dan progessif, serta terbuka dengan dunia luar. Keterbukaan ini dihadirkan untuk mengembangkan tradisi salaf akademik pesantren dan keilmuan modern.

Pada poin pentingnya literasi digital, transformasi literasi pesantren yang progressive memang perlu disambut untuk perluasan pengetahuan santri, tetapi literasi ini juga perlu untuk diantisipasi dan dibina. Hal ini memperhatikan bahwa tidak semua informasi dalam literasi digital sejalan dengan nilai nilai keislaman pesantren yang mengedepankan pandangan Islam moderat (tawasut). Pada literasi digital marak juga konten yang tidak sejalan dengan nilai-nilai pesantren. Literasi digital di pesantren memiliki titik pijak sebagai jembatan perjumpaan akademik antara santri dengan dunia luar pesantren serta memberikan kesempatan kepada santri untuk mengelola informasi sebanyak dan sebaik mungkin. Di sini, santri diberi kebebasan untuk memilih dan memilah literature apa saja yang akan mereka baca sebagai referensi pemahaman mereka terhadap kajian keislaman dan kepesantrenan. Akan tetapi literasi digital juga memiliki titik kritis, yaitu massifnya Islamisme, Hoax dan konservatifisme agama yang dibungkus dalam kajian popular keagamaan. Lebih lanjut, titik matinya literasi digital di pesantren adalah ketika santri tidak mampu mengelola dan memfilter diskursus keislaman yang ada, maka pada titik tertentu literasi digital akan lebih dominan dari pada literasi turast yang dikembangkan oleh pesantren.

\section{METODE PELAKSANAAN}

Metode dalam pelaksanaan Pengabdian Kepada Masyarakat adalah dengan metode integrating visual thinking method. Metode integrating visual thinking merupakan penemuan metode terbaru dengan konsep looking, seeing, imagining, thinking, showing and telling. Materi diberikan oleh dosen dengan memberikan gambaran visual diiringi ceramah tentang literasi digital, urgensi dan cara pemanfaatan literasi digital, danliterasi anti hoax. dan bagaimana meminimalisir bahaya pada anak. Selanjutnya diadakan diskusi tanya jawab terkait materi literasi digital. Dimana antara pemateri dan audien akan saling sharing pengetahuan. Materi akan diberikan oleh dosen yang mempunyai background pendidikan agama (pesantren). Adapun tempat penyuluhan di Ponpes Rahmatutthoyibah Al Iflahah jln Ki Cakung desa Kandawati kecamatan gunung Kaler kab Tangerang.

Kemampuan melakukan studi literasi informasi dirasa penting untuk mendukung setiap aspek kehidupan. Studi literasi yang benar dan mendalam juga menjadi syarat utama agar informasi yang ingin dibagikan menjadi akurat dan dapat dipertanggungjawabkan, sehingga menghindari tersebarnya Hoax. Tidak hanya itu studi literasi penting, karena dapat dipakai untuk membuat keputusan. Tidak bisa dipungkiri bahwa internet menjadi lahan basah penyebaran hoaks. Masyarakat mestinya bisa 
belajar bahwa informasi yang kelihatannya valid, ternyata mengandung kebohongan yang tak bisa diampuni. Sehingga, dalam menerima berita, seseorang perlu diam sejenak untuk mencerna informasi tersebut, baru setelah yakin bahwa berita itu bukan merupakan kebohongan, boleh menyebarkannya. Mengacu pada data yang dirilis oleh Kementrian Komunikasi dan Informatika, pada tahun 2016 saja ada hampir 800 ribu akun, baik media sosial maupun portal online, yang telah diblokir karena mengandung konten hoaks maupun ujaran kebencian. Tahun 2017, ada sekitar 600 akun yang diblokir karena melakukan tindakan yang sama. Data kementrian tersebut bisa menjadi warning bahwa Indonesia darurat hoaks. Warganet di manapun di Indonesia mesti menyadari status 'darurat hoaks' ini, supaya dalam beraktivitas di dunia maya bisa terkontrol, dan tidak langsung berbagi informasi ketika belum memastikan kebenarannya. Karena, diakui atau tidak, acapkali reaksi masyarkat berawal dari berita hoaks yang tersebar di dunia maya.

\section{HASIL DAN PEMBAHASAN}

Literasi merupakan keterampilan penting dalam hidup. Sebagian besar proses pendidikan bergantung pada kemampuan dan kesadaran literasi. Budaya literasi yang tertanam dalam diri peserta didik memengaruhi tingkat keberhasilannya, baik di sekolah maupun dalam kehidupan bermasyarakat. Hal yang paling mendasar dalam praktik literasi adalah kegiatan membaca. Keterampilan membaca merupakan fondasi untuk mempelajari berbagai hal lainnya. Kemampuan ini penting bagi pertumbuhan intelektual peserta didik. Melalui membaca peserta didik dapat menyerap pengetahuan dan mengeksplorasi dunia yang bermanfaat bagi kehidupannya. Membaca memberikan pengaruh budaya yang amat kuat terhadap perkembangan literasi peserta didik. Sayangnya, sampai saat ini prestasi literasi membaca peserta didik di Indonesia masih rendah, berada di bawah rata-rata skor internasional.

Data dari United Nations Educational, Scientific, and Cultural Organisation (UNESCO) menunjukkan, minat baca anak Indonesia hanya 0,1\%. Artinya dari 10.000 anak bangsa, hanya satu orang yang senang membaca.1 Permendikbud Nomor 23 Tahun 2015 menyatakan perlunya sekolah menyisihkan waktu secara berkala untuk pembiasaan membaca sebagai bagian dari penumbuhan budi pekerti. Meskipun begitu, banyak referensi menegaskan bahwa program membaca bebas tidak cukup hanya sekadar menyediakan waktu tertentu (misalnya lima belas menit setiap hari) bagi peserta didik untuk membaca. Agar program membaca bebas dapat berjalan dengan baik, sekolah perlu memastikan bahwa warga sekolah memiliki persepsi dan pemahaman yang sama tentang prinsip- prinsip kegiatan membaca bebas dan bagaimana cara pelaksanaan dan pengelolaan program. Banyak pihak meyakini Asia akan menjadi pusat perekonomian dunia, pendidikan yang bermutu bagus di Asia mampu berfungsi sebagai kekuatan yang memiliki energi yang luar biasa besar.

Masyarakat yang tidak memiliki kesiapan dalam menerapkan teknologi informasi, dan juga yang tidak melek terhadap informasi yang dibawa media menimbulkan berbagai permasalahan. Bagi anak-anak, tidak melek media mengakibatkan mulai dari kecanduan menonton tayangan televisi, bermain games online, chatting melalui social media, konten pornografi internet, infotainment, hingga berita kriminal. Bagi remaja, tidak melek media mengakibatkan perilaku konsumtif (terhadap pulsa internet), konten 
sinetron, musik, dan reality show. Remaja menganggap bahwa citra yang muncul di televisi adalah sesuatu hal yang nyata, sehingga mereka mencitrakan diri sebagai tokohtokoh sinetron dan penyanyi, mulai dari gaya berpakaian, potongan rambut, hingga perilaku sehari-hari. Bagi ibu-ibu, selain menjadi konsumtif, tidak melek media dapat mencontohkan perilaku kecanduan konten media pada anak, sampai dengan menyerahkan pengasuhan anak pada televisi. Kegagapan dalam teknologi informasi ini menyebabkan beberapa peristiwa naas terjadi. Kasus penyebaran video porno siswa yang berakhir dengan hilangnya masa depan juga terjadi.

Rendahnya budaya literasi dapat menyebabkan kegagapan dalam menghadapi teknologi komunikasi dan informasi yang berkembang luar biasa pada hari ini. Masyarakat mudah mengakses dan menyebarkan berita-berita atau informasi hoax. Tak sedikit kasus bullying, penipuan, dan pornografi/aksi yang berawal dari kurang cerdasnya berliterasi, baik yang terjadi secara langsung maupun tidak langsung. Karena pentingnya literasi digital bagi santri sebagai transformasi literasi pesantren yang progressive perlu disambut untuk perluasan pengetahuan santri, tetapi literasi ini juga perlu untuk diantisipasi dan dibina. Hal ini memperhatikan bahwa tidak semua informasi dalam literasi digital sejalan dengan nilai nilai keislaman pesantren yang mengedepankan pandangan Islam moderat (tawasut).

Maka kami melakukan hal-hal sebagai berikut :

1). Memberikan penyuluhan kepada santri dan dewan guru tentang urgensi literasi digital.

2). Melatih santri dan dewan guru untuk terampil menggunakan literasi digital sebagai media pembelajaran.

\subsection{Definisi Literasi Digital}

Pada tahun 2018 United Nations Educational, Scientific and Cultural Organization (UNESCO) mendefinisikan literasi digital sebagai kemampuan individu untuk mengakses, memahami, membuat, mengomunikasikan, dan mengevaluasi informasi melalui teknologi digital. Sementara Jaringan Pegiat Literasi Digital (Japelidi) pada tahun yang sama menyebutkan literasi digital terdiri atas tiga elemen, yaitu pengetahuan, kompetensi, dan lokus personal. Pengetahuan dan kompetensi artinya individu diharapkan memahami dan mengimplemntasikan konsep literasi digital, sedangkan lokus personal artinya kebutuhan literasi digital individu satu dan lainnya bisa saja berbeda. Japelidi juga mengelompokkan literasi digital menjadi 10 kompetensi, yaitu mengakses, menyeleksi, memahami, menganalisis, membuktikan, mengevaluasi, mendistribusi, memproduksi, berpartisipasi, dan kolaborasi.

Dari berbagai definisi yang ada, kami menekankan pada satu tahapan awal yakni akses terhadap teknologi sebagai salah satu hal yang paling krusial. Kenapa krusial? Karena tanpa adanya akses, tentu tidak mungkin bagi individu dapat masuk/beralih menuju tahapan kemampuan literasi digital lainnya.

\subsection{Tantangan}

Namun salah satu permasalahan yang dihadapi Indonesia ialah masih adanya kesenjangan atas akses informasi melalui teknologi digital, terutama bagi masyarakat yang hidup pada garis kemiskinan, tinggal di pedesaan, berusia lanjut, 
dan penyandang disabilitas. Pada survey APJII pada tahun 2017 menggambarkan angka penetrasi internet di perkotaan dan pedesaan ialah $72,41 \%$ vs $48,25 \%$. Sedangkan mayoritas pengguna berada pada rentang usia $15-19$ tahun, dan hanya $16,2 \%$ yang berusia di atas 60 tahun. Tantangan lainnya pendidikan literasi digital mayoritas masih dilaksanakan pada level perguruan tinggi. Padahal mayoritas pengguna aktif internet tidak hanya ada pada perguruan tinggi.

Bagi mereka yang belum menggunakan internet hambatan terbesarnya sebagai berikut:

1). Tidak tahu cara menggunakan teknologi;

2). Tidak tertarik atau tidak merasa perlu menggunakan karena tidak melihat fungsi internet;

3). Mahalnya biaya.

Kesempatan yang tidak berimbang ini seringkali disebut dengan kesenjangan digital. Kesenjangan digital sendiri didefinisikan sebagai kesenjangan antara individu, rumah tangga, bisnis, dan area geografis pada level sosial-ekonomi yang berbeda terkait dengan peluang mereka dalam mengakses TIK dan penggunaannya untuk berbagai kegiatan.

Tidak bisa dipungkiri bahwa internet menjadi lahan basah penyebaran hoaks. Masyarakat mestinya bisa belajar bahwa informasi yang kelihatannya valid, ternyata mengandung kebohongan yang tak bisa diampuni. Sehingga, dalam menerima berita, seseorang perlu diam sejenak untuk mencerna informasi tersebut, baru setelah yakin bahwa berita itu bukan merupakan kebohongan, boleh menyebarkannya. Berangkat dari kondisi tersebut, Berikut ini Tips Cerdas Literasi Informasi

1). Know, Kenali kebutuhan informasi. Gunakan pemetaan pikiran (mindmap) untuk mempermudah. Gunakan aplikasi online free app di telpon pintar atau komputer, seperti Coggle, Mindly, dsb.

2). What, Rinci hal-hal yang tidak/belum diketahui. Gunakan pertanyaan bantuan seperti detil dan pengaruh untuk membantu mengembangkan rumusan masalah dari topik dan merinci berbagai informasi atau data yang harus dibutuhkan.

3). How, Dapatkan data dan informasi AVR (Akurat, Valid, dan Relevan) untuk menjawab rumusan masalah dengan menggunakan: dari berbagai sumber informasi yang sangat berlimpah di jaman 'now' dengan efektif dan efisien: Operator "Boolean" (AND atau +, OR atau |, NOT atau -) dan berbagai sintaks Google (Google cheat dapat diunduh dari http://bit.ly/cheatsheetgoogle) untuk mempersempit pencarian di mesin pencari Google atau pangkalan data. Gunakan Mendeley (http://mendeley.com) untuk mengelola dokumen atau file yang didapat dari pangkalan data berbayar (Bisa diakses dari http://library.uph.edu) maupun portal informasi online bebas bayar (Google Scholar, Academia, Research Gate, Neliti, DOAJ, dsb.).

4). Learn, Ekstrasi informasi atau data untuk menjawab rumusan masalah. Gunakan metode 5-W-1-H. Gabungkan informasi dan data yang diperoleh untuk menjawab masalah dan membangun pengetahuan baru. Gunakan aplikasi online untuk menghasilkan tampilan informasi yang menarik seperti Canva, Pear Deck (poster dan presentasi), Pictochart(infografis), Powtoon, Emaze(Presentasi animasi), dsb. 
5). Share (Bagikan pengetahuan kepada masyarakat), Sebagai bagian dari masyarakat jaman "Now" yang berbasis informasi, tentunya harus berbagi pengetahuan. Hal-hal yang perlu diperhatikan sebelum membagikan: Buatlah paket informasi dalam format yang sesuai dengan media yang akan dibagikan serta media yang akan digunakan, misalnya format video untuk media youtube, infografis untuk media Instagram, presentasi bentuk pdf untuk media facebook dst. Pastikan informasi tidak mengandung hoax yang berisi isu SARA.

\section{SIMPULAN}

Kegiatan Pengabdian Kepada Masyarakat dengan tema "Urgensi Literasi Digital bagi Santri Milenial di Ponpes Rahmatutthoyibah Al Iflahah jln Ki Cakung desa Kandawati kecamatan gunung Kaler kab Tangerang " yang telah dilaksanakan oleh tim pengabdian kepada masyarakat program studi Manajemen dan Program Studi S1 Akuntansi Universitas Pamulang terlaksana dengan baik sesuai dengan yang direncanakan. Kegiatan berlangusng selama tiga hari. Acara ini terlaksana atas kerjasama dengan berbagai pihak seperti Yayasan Sasmita Jaya, dosen Program Studi Manajemen, Program Studi S1 Akuntansi serta Ponpes Rahmatutthoyibah Al Iflahah jln Ki Cakung desa Kandawati kecamatan gunung Kaler kab Tangerang. Pelatihan ini berhasil memberikan bekal pengetahuan kepada santri dan dewan guru Ponpes Rahmatutthoyibah Al Iflahah terkait dengan literasi digital.

Kesimpulan besar yang dapat ditarik yaitu ketika merancang suatu program literasi digital, hal yang harus dilakukan adalah memahami terlebih dahulu apa hambatan dari target sasaran. Setelah mengetahui hal tersebut baru dapat disusun program yang sesuai. Setidaknya ada tiga saran kepada para stakeholder literasi digital. Pertama diperlukan gerakan inisiasi literasi digital nasional yang mampu menjangkau seluruh kalangan, terutama mereka yang masih memiliki hambatan mengakses internet, karena akses menjadi kunci untuk tahapan lainnya. Kedua, perlu dibuat roadmap literasi digital untuk memetakan tingkatan literasi digital pada berbagai kelompok masyarakat. Hal tersebut karena dibutuhkan pendekatan berbeda untuk segment masyarakat yang berbeda. Ketiga, perlu dibuat kebijakan untuk mendorong litersi digital yang masif. Aturan terkait misinformasi pada platform media sosial, perlindungan data, memasukkan kurikulum literasi digital di Sekolah atau pesantren.

\section{DAFTAR PUSTAKA}

Ahyar, Muzayyin. (2017). Islamic Clicktivism: Internet, Democarcy and Contemporary Islamic Activism in Surakarta. Studia Islamika Volume 24, Nomor 3.

Bagir, Haidar. (2015). Fundamentalisme Agama, Fenomena Kaum Urban. Jakarta, Republika.co.id, tertanggal 29 Mei 2015. Diakses pada 25 Januari 2019.

Hosen Nadirsyah. (2008). Online Fatwa in Indonesia: From Fatwa Shoping to Googling Kyai. Research gate.

Nurjanah, Ervina. (2018). Hubungan Literasi Digital dengan Kualitas Penggunaan EResources. Pesantren virtual.com Http://ejournal.undip.ac.id/index.php/lpustaka 